\title{
NÃO À RETRATAÇÃO? O LUGAR DA INTERVENÇÃO PENAL NO CRIME DE VIOLÊNCIA DOMÉSTICA CONTRA A MULHER ${ }^{\mathrm{i}}$
}

Sumário: 1 A Lei Maria da Penha diante da realidade dos conflitos domésticos e das expectativas das mulheres vítimas. $2 \mathrm{O}$ "tipo penal" de violência doméstica e as discussões acerca de sua ação penal. 3 Em busca de uma conclusão: o lugar do Direito penal no conflito doméstico. Referências.
Carolina Salazar l'Armée Queiroga de Medeiros ii Marília Montenegro Pessoa de Mello ${ }^{\text {iii }}$

\section{Resumo}

O presente trabalho propõe-se a discutir o lugar da intervenção penal no âmbito violência doméstica e familiar contra a mulher. Na pesquisa, portanto, confrontar-se-ão os propósitos protecionistas da Lei Maria da Penha e os anseios das mulheres em situação de violência, a fim de averiguar a possibilidade de uma abertura político-criminal para o afastamento da incidência do sistema penal nos conflitos domésticos em atenção às vontades das mulheres vítimas de violência, especialmente através da avaliação da natureza da ação penal do crime de lesão corporal leve - violência doméstica - praticado contra

\footnotetext{
${ }^{\mathrm{O} O}$ presente trabalho está vinculado às pesquisas desenvolvidas pelo Grupo Asa Branca de Criminologia - www.asabrancacriminologia.blogspot.com.br. ii Mestranda do Programa de Pós-Graduação em Direito da Universidade Católica de Pernambuco. Bolsista CAPES/PROSUP.

iii Doutora em Direito pela Universidade Federal de Santa Catarina e Mestre em Direito pela Universidade Federal de Pernambuco. Professora do Programa de Mestrado em Direito da Universidade Católica de Pernambuco e da Graduação em Direito da UNICAP e UFPE.
} 
a mulher no seio familiar.

Palavras-chave: Lei Maria da Penha. Violência doméstica e familiar contra a mulher. Ação penal. Lesão corporal leve. Expansionismo penal.

\begin{abstract}
This paper aims to discuss about criminal intervention's role on domestic and familiar violence against women. Therefore, Maria da Penha Law's protectionist purposes were confronted with the demands of women in violence situation, in order to evaluate the possibility of a criminal policy opening, regarding women victim's wills, so the criminal system's incidence could be removed out of these domestic conflicts, especially by the change of criminal prosecution action's nature on mild body injury practiced against women in the family environment.
\end{abstract}

Keywords: Maria da Penha Law. Domestic and familiar violence against women. Criminal prosecution action's nature. Mild body injury. Penal expansionism.
1 A LEI MARIA DA PENHA DIANTE DA REALIDADE DOS CONFLITOS DOMÉSTICOS E DAS EXPECTATIVAS DAS MULHERES VÍTIMAS

ineficiência do sistema penal para pre-
venir e erradicar a criminalidade não é
diferente quando o assunto é a violência doméstica e familiar contra a mulher. Nesse sentido, estudos divulgados por Larrauri ${ }^{1}$ demonstraram que, na Espanha - conquanto exista a rígida Lei Orgânica n. 11/2003, a qual em muito inspirou a brasileira Lei "Maria da Penha" -, os índices de homicídios praticados contra as mulheres por seus parceiros não diminuíram. Deveras, resultados revelam, ainda, que as mulheres em situação de violência não vislumbram a justiça penal como um sistema apto a ajudá-las a solucionar seus problemas.

Os motivos que conduzem a decepção feminina com o sistema penal são vários, no entanto, todos eles convergem para um único fato (de inúmeros efeitos negativos): a apropriação, pelo sistema penal, dos conflitos das vítimas, de sorte que suas vozes e expectativas são completamente olvidadas e o problema não é solucionado.

O procedimento processual penal, tal como é concebido na modernidade, relega à vítima um papel secundário, tanto que, após a informação oficial da ocorrência ou após a representação penal, ela passa a ser uma mera informante, quiçá uma testemunha. Há, assim, uma estruturação processualística que enseja a completa neutralização da vítima ${ }^{2}$. A prioridade da ação Estatal não consiste na contemplação dos sentimentos da vítima ou dos efeitos da prática delitiva sobre sua vida, mas na persecução penal daquele que praticou um ato criminoso. Após a expropriação do conflito pelo Estado, portanto, o suposto agressor não tem que dar satisfações à ofendida, mas deve prestar contas ao próprio Estado, detentor da ação penal.

As vítimas, no sistema penal, portanto, são ignoradas; seus depoimentos são reduzidos a

\footnotetext{
${ }^{1}$ LARRAURI, Elena. La intervencion penal para resolver un problema social. Revista Argentina de Teoría Jurídica, Buenos Aires, v. 11, n. 1, p. 01-22, ago. 2011, p. 1-2.

${ }^{2}$ FAYET JÚNIOR, Ney; VARELA, Amanda Gualtieri. A ação (penal) privada subsidiária da pública: das vantagens ou desvantagens da participação do ofendido na atividade jurídico-penal. Porto Alegre: Elegantia Juris, 2014.
} 
termo e, para os oficiais, tudo que importa ao reportá-los são as circunstâncias relatadas que fazem o fato subsumir à norma. Os documentos oficiais assemelham-se a formulários com uma narrativa monótona, impessoal e sem variações, que leva à completa redução da complexidade dos conflitos. No enquadramento legal, portanto, o encadeamento da briga é totalmente refutado e reduzido àquele único ato que define o crime ${ }^{3}$.

Necessário destacar, ainda, um dos aspectos mais relevantes e diferenciadores dos conflitos de gênero: o comprometimento emocional entre as partes envolvidas. As normas do direito penal não contemplam o envolvimento afetivo entre os integrantes dos polos ativos e passivo do crime; elas programam, normalmente, situações corriqueiras e não complexas nas quais as partes não se conhecem, como uma briga em um bar ou um roubo eventual. No caso da violência doméstica e familiar contra a mulher, entretanto, a briga ou agressão é concomitante à existência de uma relação familiar, em que os integrantes partilham laços de amor, intimidade e carinho. Logo, os casos envolvem uma carga subjetiva muito grande e o Direito Penal não foi estruturado para contemplá-la ${ }^{4}$.

Em decorrência dessas relações íntimas e de afeto existentes, diversas pesquisas apontam que as mulheres violadas, ao tornarem público o conflito doméstico e familiar, normalmente não querem retribuir o mal causado pelo agressor, criminalizando-o e punindo-o. Elas desejam apenas romper o ciclo de violência e restabelecer o pacto familiar e a paz no lar. Até mesmo as poucas mulheres que desejam a separação, no caso de violência conjugal, não almejam a persecução penal do agressor; elas preferem que a coesão familiar seja mantida, especialmente quando há filhos envolvidos. Logo, as vítimas se utilizam da ameaça de uma condenação no intuito de fazer cessar a violência ${ }^{5}$.

A vontade feminina foi inicialmente evidenciada nas Delegacias Especializadas de Atendimento à Mulher (DEAMs), criadas anteriormente às Leis 9.099/1995 e 11.340/2006, e consideradas, à época, a principal política de combate e prevenção à violência doméstica no Brasil. Nelas, na prática, desviava-se da função de criminalização do agressor e o aparato da autoridade policial era utilizado pelas mulheres para a coação informal do varão e solução das desavenças domésticas. As vítimas, pois, registravam a ocorrência na delegacia, mas, retiravam-na após a "mediação policial", para evitar que a Lei, impessoal, interviesse na relação privada ${ }^{6}$.

Afirma-se que a mesma motivação feminina foi observada ao longo de processos penais nos quais a mulher não tinha mais a possibilidade de retratar a representação criminal ou sequer teve a possibilidade de representar, quando se tratava de ação penal pública incondicionada. Nesses casos, observou-se que as mulheres se utilizavam de diversos artifícios para impedir a condenação dos seus agressores, tal que frequentemente modificavam seus depoimentos, atribuíam as lesões a acidentes e quedas e até mesmo assumiam ser responsáveis pela causação dos ferimentos (autolesões) ${ }^{7}$.

Quando tornam públicas as relações conjugais violentas estão, ao mesmo tempo, orientadas para uma ação cujo sentido é a restituição da solidariedade perdida na interação familiar e no espaço privado. Este sentido implica restabelecer vínculos da dimensão emocional e dos afetos que não se restringem à esfera da conjugalidade e não visam, ao menos com exclusividade, à 'recomposição do casal' [...]. Aquelas que se separam, ou que anunciaram a ruptura do vínculo conjugal como um desdobramento que se seguiria ao registro do caso na delegacia, rejeitaram a possibilidade do 'ex'

\footnotetext{
${ }^{3}$ CELIS, Jacqueline Bernat de; HULSMAN, Louk. Penas perdidas: o sistema penal em questão. Niterói: Luam, 1993, p. 80,82.

${ }^{4}$ CELMER, Elisa Girotti. Sistema penal e relações de gênero: uma análise de casos referentes à Lei 11.340/06 na comarca do Rio Grande/RS. In: SEMINÁRIO INTERNACIONAL FAZENDO GÊNERO, 9, 2010, Florianópolis. Anais... [recurso eletrônico] / Seminário Internacional Fazendo Gênero 9: diásporas, diversidades, deslocamentos. Florianópolis: Universidade Federal de Santa Catarina, 2010. p. 1-9. Disponível em: <http://www.fazendogenero. ufsc.br/9/resources/anais/1278298189_ARQUIVO_SISTEMAPENALERELACOESDEGENERO-fazendogenero.pdf>. Acesso em: 13 mar. 2012.

${ }^{5}$ PASINATO, Wânia. Violência contra as mulheres e legislação especial, ter ou não ter? Eis uma questão. Revista Brasileira de Ciências Criminais. São Paulo, Revista dos Tribunais, n. 70, p. 321-360, jan.-fev. 2008, p. 347-348.

${ }^{6}$ MORAES, Aparecida Fonseca; SORJ, Bila. Os paradoxos da expansão dos direitos das mulheres no Brasil. In: MORAES, Aparecida Fonseca; SORJ, Bila (Coord.). Genero, violencia e direitos na sociedade brasileira. Rio de Janeiro: 7 letras, 2009, p. 15.

7 PASINATO, Wânia. Violência contra as mulheres e legislação especial, ter ou não ter? Eis uma questão. Revista Brasileira de Ciências Criminais. São Paulo, Revista dos Tribunais, n. 70, p. 321-360, jan.-fev. 2008, p. 348.
} 
ser preso. A ideia de 'recuperar' o agressor acionando o recurso policial tem o objetivo, para a mulher, de romper com a situação violenta que a atinge, mas também é uma iniciativa para pacificar o circuito de relacionamento familiar no qual estavam incluídos os filhos ou mesmo outros parentes ${ }^{8}$.

Assim, as mensagens midiáticas de que as vítimas e suas famílias clamam por vingança e punição são bastante falaciosas. Afirma-se que o sentimento da vindita até existe, principalmente logo após a ocorrência do fato, daí a existência de calorosos depoimentos veiculados nos meios de comunicação. Entretanto, esse sentimento não é generalizado e muito menos duradouro. Pesquisas revelam que as vítimas, em geral, não vislumbram a necessidade de um processo penal e, até mesmo em casos mais graves, preferem a resolução do conflito fora do mundo jurídico-penal e punitivo9.

As vítimas querem, nesse contexto, proteção e disponibilidade de formas diversas e concretas para a solução dos conflitos domésticos e não necessariamente a punição do agressor. No entanto, a expropriação do conflito pelo Estado, além de reduzir as complexidades dos conflitos por não contemplar suas peculiaridades e múltiplas facetas, redunda na apresentação de uma única reação à situação conflituosa: a resposta punitiva mediante a imposição de uma pena privativa de liberdade.

O conflito, portanto, é subtraído, por completo, da órbita de alcance das partes envolvidas e as múltiplas formas de solução disponíveis são forçosamente substituídas pela aplicação de uma lógica punitiva ${ }^{10}$.

Ademais, a crença de que com a punição do agressor a vítima poderá descansar e encontrar a sua paz é tão falaciosa quanto os ideais de ressocialização e prevenção que acompanham o modelo de justiça encarceradora. Quando o processo termina com a imposição de uma medida constritiva, a mulher, que ainda partilha sentimentos amorosos pelo agressor, ao ver o sofrimento do condenado no cumprimento da pena, sente-se uma violadora e não mais uma vítima, já que vislumbra o mal causado ao agressor muito mais gravoso do que aquele que ele lhe causou ${ }^{11}$. Outrossim, os efeitos da pena transcendem à pessoa do condenado, de modo que afetam substancialmente a família.

A imposição da pena ao agressor, portanto, implica também a imposição de uma sanção à vítima. Com a intervenção penal, a mulher fica desamparada em todos os sentidos: não possui mais apoio econômico (seja porque ela já não trabalhava, seja porque a renda familiar não será mais complementada); não há mais a afetividade daquele ente querido no seio familiar; e o estigma de ser "filha", "mãe" ou "mulher" de um condenado a acompanha em qualquer âmbito social, dificultando suas relações e obtenção de trabalho ${ }^{12}$.

Como se não bastassem esses efeitos negativos, as mulheres, que normalmente não abandonam seus familiares durante a reclusão, sejam eles filhos, pais ou companheiros amorosos, comparecem à prisão nos dias de visita e, graças aos procedimentos de segurança carcerários, submetem-se a revistas íntimas degradantes. Nesse ínterim, percebe-se que a condição de vítima da mulher perpetua-se com a condenação de seu agressor; o vitimizador, no entanto, agora é o próprio sistema penal.

Ante o exposto, percebe-se que, em regra, as mulheres vítimas da violência doméstica não desejam a existência do procedimento penal. A Lei Maria da Penha, no entanto, impossibilitou qualquer forma de diálogo e de exposição das vontades das vítimas, seja pela vedação da utilização dos institutos alternativos ao processo, seja pela escolha da regra da ação penal pública incondicionada. Paradoxalmente, pois, a lei que surgiu

\footnotetext{
${ }^{8}$ GOMES, Carla de Castro; MORAES, Aparecida Fonseca. O caleidoscópio da violência conjugal: instituições, atores e políticas públicas no Rio de Janeiro. In: MORAES, Aparecida Fonseca; SORJ, Bila (Coord.). Gênero, violência e direitos na sociedade brasileira. Rio de Janeiro: 7 letras, 2009 , p. 101. ${ }^{9}$ CELIS, Jacqueline Bernat de; HULSMAN, Louk. Penas perdidas: o sistema penal em questão, p. 116-118.

${ }^{10}$ OTERO, Juan Manuel. A hipocrisia e a dor no sistema de sanções do direito penal. Discursos Sediciosos: crime, direito e sociedade, Rio de Janeiro, ano 12 , n. $15 / 16$, p. 45-63, 2007, 1 e 2 semestres 2008, p. 47-49.

${ }^{11}$ ALENCAR, Daniele Nunes de; MELLO, Marília Montenegro Pessoa de. A Lei Maria da Penha e sua aplicação na cidade de Recife: uma análise crítica do perfil do "agressor" nos casos que chegam ao Juizado da mulher (anos 2007-2008). Revista Sociais e Humanas. v. 24, n. 2, p. 9-21, jul./dez. 2011 , p. 13. ${ }^{12}$ HERMANN, Leda Maria. Violência doméstica e os juizados especiais criminais: a dor que a lei esqueceu. Campinas: Servanda, 2002 , p. 56-57.
} 
no intuito de dar voz e poder às mulheres impõe um procedimento que impede que elas falem e que tenham vez.

A lógica do sistema, portanto, é enaltecer a vítima e seus sentimentos até a autorização social da expansão do poder punitivo, com a criação da conduta delituosa que permite a atuação estatal. Após a apropriação do conflito pela instância pública, o sistema neutraliza as vítimas e torna-as inócuas, de modo que elas sequer podem decidir a respeito da via mais adequada para resolver sua situação. A lei impõe, por conseguinte, um regresso à época em que as mulheres eram ignoradas e não tinham voz no espaço público.

Nesse contexto, a expansão do Direito Penal no ambiente privado-familiar deixou de contemplar as relações de afeto e intimidade existentes entre vítimas e acusados, como também as expectativas e necessidades das mulheres violadas, que, preocupadas com o bem-estar da família e almejando a cessação da violência e o restabelecimento da solidariedade familiar, não se voltam para a persecução penal de seus agressores, por quem têm sentimentos afetivos. Logo, quando conhecem a possibilidade de privação da liberdade do sujeito ativo, as vítimas têm dificuldades em denunciar o abuso sofrido.

[...] legislações muito rígidas desestimulam as mulheres agredidas a denunciarem seus agressores e registrarem suas queixas. Sempre que o companheiro ou esposo é o único provedor da família, o medo de sua prisão e condenação a uma pena privativa de liberdade acaba por contribuir para a impunidade [...]. É urgente que se amplie o conhecimento das experiências alternativas à imposição de penas nesta área, pois já existe evidência de que, em vários casos, o encarceramento de homens pode aumentar, ao invés de diminuir, os níveis de violência contra a mulher e as taxas gerais de impunidade para esse tipo de crime $^{13}$.

Nesses termos, pois, a intervenção penal jamais poderá ser considerada como um meio efetivo para a solução de conflitos domésticos.
Em verdade, muitos dos conflitos pessoais, os quais são enquadráveis na previsão taxativa da lei penal, na atualidade, são resolvidos através de meios não disponibilizados pelo sistema penal. Apenas uma ínfima parte deles é resolvida na justiça criminal. Na maioria das vezes, as soluções são encontradas pelos próprios membros da família ou com o auxílio de profissionais que apontem uma alternativa viável ${ }^{14}$.

As mulheres que se encontram em situação de violência, quando procuram algum auxílio é porque necessitam urgentemente de algum meio que possa fazer cessá-la de imediato. Aquelas mais independentes e que possuem recursos financeiros têm a possibilidade de sair de casa e procurar ajuda em outras instâncias, que não a penal, ao lado de psicólogos, grupos de apoio, hospitais particulares, até mesmo o auxílio de outros familiares. Enfim, há uma infinidade de recursos muito mais eficientes disponíveis a essas mulheres para a cessação da violência ${ }^{15}$. Para as mulheres pertencentes às parcelas mais carentes da sociedade e dependentes financeiramente do companheiro, entretanto, o Estado só disponibiliza o aparato policial, totalmente despreparado para acudi-las. Não há (ou há precariamente) a disponibilização de abrigos, centros de apoio com serviço social ou hospitais.

Pode-se até arguir que a Lei Maria da Penha disponibilizou às mulheres as medidas protetivas de urgência e o apoio de uma equipe multidisciplinar especializada e não se pode negar a importância do viés extrapenal da legislação. No entanto, em razão de sua natureza cautelar, os aparatos protetivos e assistenciais que a lei oferta são condicionados à existência de uma ação penal. As medidas de proteção, portanto, só vêm com a intervenção penal; quando o processo acaba ou é interrompido, as medidas também cessam. Em suma, o Estado só protege aquelas que permitem a sua atuação punitiva (normalmente não desejada pelas mulheres).

\footnotetext{
${ }^{13}$ LEMGRUBER, Julita. A mulher e o sistema de justiça criminal - Algumas notas. Revista Brasileira de Ciências Criminais, n. 36, p. 381, out.-dez. 2001, p. 381.

${ }^{14}$ CELIS, Jacqueline Bernat de; HULSMAN, Louk. Penas perdidas: o sistema penal em questão, p. 74

${ }^{15}$ ALENCAR, Daniele Nunes de; MELLO, Marília Montenegro Pessoa de. A Lei Maria da Penha e sua aplicação na cidade de Recife: uma análise crítica do perfil do "agressor" nos casos que chegam ao Juizado da mulher (anos 2007-2008). Revista Sociais e Humanas. v. 24, n. 2, p. 9-21, jul./dez. 2011, p. $10-11$.
} 
Há, pois, uma lógica muito particular no procedimento da Lei Maria da Penha, a qual, certamente, não está focada na proteção feminina e o processo pode ser visto como um fim em si mesmo. Críticas demasiadas são feitas ao fato de as mulheres, para terem acesso aos recursos protetivos disponibilizados pela lei, precisarem, necessariamente, recorrer à polícia. Assevera-se que as autoridades não deveriam estar focadas no aumento do número de denúncias, mas na diminuição da violência doméstica contra as mulheres ${ }^{16}$. A Lei, portanto, foi muito positiva ao pensar no apoio necessário às mulheres, mas limitada ao condicionar a proteção à necessidade de uma ação penal.

\section{O “TIPO PENAL” DE VIOLÊNCIA DOMÉS- TICA E AS DISCUSSÕES ACERCA DE SUA AÇÃO PENAL}

A Lei "Maria da Penha" não criou novos tipos penais, mas conceituou e identificou as formas de violência doméstica contra a mulher, que pode ser física, psicológica, sexual, patrimonial e moral ${ }^{17}$. Diante de conceito tão abrangente, o legislador praticamente não deixou, no ordenamento jurídico brasileiro, infrações penais livres da possibilidade de serem praticadas contra a mulher no contexto doméstico e familiar.

Outrossim, para que todas essas infrações passassem a ser vistas como mais graves, no lugar de qualificar cada uma delas, bastou o artifício legal da inserção de uma agravante penal genérica $^{18}$ no Código Penal brasileiro, para os crimes praticados no contexto da violência do- méstica contra a mulher.

Realmente, a Lei n. 11.304/2006 não criou o delito de violência doméstica porque ele já havia surgido desde o ano de 2004, também no contexto de resposta política aos clamores públicos por um maior rigor penal, com a Lei n. 10.886/2004. Este delito, tipificado no artigo $129, \$ 9^{\circ}$, do Código Penal, nada mais é do que uma qualificação da lesão corporal leve em razão da especificidade dos sujeitos passivos: ascendente, descendente, irmão, cônjuge ou companheiro, com quem o agressor conviva ou tenha convivido, independentemente de sexo ${ }^{19}$; ou do modo como é praticado pelo agente: prevalecendo-se das relações domésticas, de coabitação ou de hospitalidade.

No ano de 2006, porém, embora tenha mantido exatamente a mesma redação do preceito primário do $\$ 9^{\circ}$ do art. 129, a Lei Maria da Penha aumentou o referencial quantitativo em abstrato da pena do crime de violência doméstica - o mínimo passou de 6 (seis) para 3 (três) meses e o máximo de 1 (um) para 3 (três) anos - de modo que o crime perdeu o caráter de baixa lesividade descrito na Lei n. 9.099/1995. Percebe-se, assim, que as referidas modificações no referido tipo incriminador fizeram com que sua apreciação fosse afastada do âmbito dos Juizados Especiais Criminais.

Mesmo que a superação do referencial máximo em abstrato de dois anos da pena do crime de violência doméstica não tivesse ocorrido, o artigo 41 da Lei n. 11.340/2006 afastou expressamente a aplicação da Lei n. 9.099/1995 aos crimes ${ }^{20}$ praticados no contexto da violência doméstica contra a mulher. Afirma-se que o artigo 41 representa o maior enrijecimento legal da Lei

\footnotetext{
${ }^{16}$ LARRAURI, Elena. La intervencion penal para resolver un problema social. Revista Argentina de Teoría Jurídica, Buenos Aires, v. 11, n. 1, p. 01-22, ago. 2011, p. 7.

${ }^{17}$ A conceituação da violência doméstica e familiar contra a mulher é obtida através da interpretação integrada dos artigos $5^{\circ}$ e $7^{\circ}$ da Lei $11.340 / 2006$.

18 "Art. 61. São circunstâncias que sempre agravam a pena, quando não constituem ou qualificam o crime: [...] I - ter o agente cometido o crime: [...] f) com abuso de autoridade ou prevalecendo-se de relações domésticas, de coabitação ou de hospitalidade, ou com violência contra a mulher na forma da lei específica.".

${ }^{19}$ Note-se que para a configuração do crime de violência doméstica, descrito no Código Penal, é desnecessária a figuração de uma mulher no polo passivo do crime. Quando a vítima for uma mulher, entretanto, as disposições da Lei 11.340/2006 imperarão.

${ }^{20}$ Embora as contravenções penais se encaixem no elástico conceito de violência doméstica contra a mulher, a Lei Maria da Penha foi categórica ao afastar da égide da Lei 9.099/95 apenas os crimes praticados naquele contexto. Quando, portanto, a prática de alguma contravenção penal caracteriza a violência contra a mulher no contexto doméstico, embora a competência para processá-las e julgá-las seja dos Juizados de Violência Doméstica e Familiar contra a Mulher, em razão da exigência de interpretação restritiva da Lei penal, os institutos despenalizadores poder-lhe-ão ser aplicados. No entanto, campo de contraditórias decisões judiciais, a decisão do STF no habeas corpus n. 106.212 deixou mais ampla a vedação da aplicação das medidas despenalizadoras quando se trata de violência doméstica. Muito embora a redação da lei seja categórica ao vedar a aplicação da Lei n. 9.099/1995 apenas aos crimes cometidos contra a mulher no contexto doméstico, a interpretação da Suprema Corte brasileira, com patente utilização imprópria do significado do gênero infração penal, estendeu a vedação às "adormecidas" contravenções penais e contrariou a imposição legal da interpretação taxativa de uma lei penal.
} 
Maria da Penha, já que, como afirmado anteriormente, a grande maioria dos crimes praticados contra a mulher no contexto doméstico e familiar é, notadamente, de menor potencial ofensivo. A vedação implicou, pois, a impossibilidade de utilização da transação penal, suspensão condicional do processo e composição civil em incontáveis casos em que, prioritariamente, seriam possíveis. Destarte, a proibição de utilização dos institutos descriminalizadores, em sentido amplo, desprogramou a possibilidade de utilização de alternativas capazes de evitar a ampliação da intervenção penal e aplicação de penas encarceradoras desumanas.

O ponto mais relevante da discussão gerada a partir da disposição do artigo 41 da Lei n. 11.340/2006, contudo, é relativo à mudança, ou não, da natureza da ação penal da lesão corporal leve qualificada pela violência doméstica. A Lei Maria da Penha não modificou a ação penal de crimes e, por conseguinte, acirrou o antigo e polêmico impasse doutrinário relativo à questão ${ }^{21}$.

Antes de entrarmos propriamente nas discussões travadas, é mister tecer algumas considerações a respeito das ações penais, especialmente a condicionada à representação do ofendido.

No direito penal brasileiro, a ação penal, de acordo com o critério subjetivo, ou seja, conforme a eleição da pessoa habilitada para promover a ação, classifica-se como de iniciativa pública ou privada. O titular da ação penal de natureza pública, nesse contexto, é o Ministério Público e o da ação penal de natureza privada é o particular que teve o seu bem jurídico agredido. Em razão do princípio da oficialidade, o qual implica no monopólio estatal da persecução penal, no ordenamento jurídico pátrio, como regra, adota-se a ação penal de natureza pública ${ }^{22}$.

No âmbito das ações penais públicas, pode-se destacar ainda a subdivisão feita segundo a exis- tência, ou não, de alguma condição para a sua procedibilidade, tal que podem ser incondicionadas ou condicionadas à requisição do Ministro da Justiça ou à representação da vítima (ou de seu representante legal). Apenas excepcionalmente, entretanto, a iniciativa da ação penal pelo parquet está condicionada a uma anterior manifestação de vontade do ofendido, que é a pessoa cujo bem jurídico foi lesionado pela prática de um fato criminoso.

Importante salientar que a titularidade da ação penal pública condicionada à representação continua a pertencer ao Ministério Público. O Estado confere à vítima apenas a possibilidade de avaliar, conforme valorações íntimas, a oportunidade e a conveniência da ação penal ${ }^{23}$. A representação da vítima constitui, pois, simultaneamente, uma autorização e um pedido para que a perseguição criminal se inicie; o Ministério Público, portanto, só pode dar início à ação penal se a vítima o autorizar, mas, após o consentimento da vítima, esta não possuirá qualquer gerência sobre a ação penal ${ }^{2425}$.

São diversas as razões de política criminal que levam o legislador a fazer com que delitos específicos sejam perseguidos apenas mediante a autorização do ofendido, mas se afirma que o ponto em comum das escolhas legislativas está "no objetivo de se evitar a imposição incondicional da 'pretensão punitiva' Estatal frente a interesses privados que lhes são opostos [Tradução nossa]"26. Embora não haja a positivação das circunstâncias que justificam a opção do legislador pela ação condicionada, doutrinariamente, faz-se a indicação de três motivações frequentemente evocadas pelo Legislativo.

A primeira explicação refere ao fato de se tratar de um crime de baixa potencialidade lesiva ao bem jurídico atingido e, portanto, de pouca relevância imediata ao interesse público. Evoca-

\footnotetext{
${ }^{21}$ Já, em 2004, com a criação do "tipo penal” da violência doméstica, alguns autores passaram a defender que a ação seria pública incondicionada, pois só haveria sentido na criação dessa forma qualificada para modificar a ação e evitar, por conseguinte, a aplicação do instituto da composição de danos (art. 74 da Lei n. 9.099/1995)

${ }^{22}$ SANTOS, Juarez Cirino dos. Direito penal: parte geral. 4. ed. Florianópolis: Conceito Editorial, 2010, p. 630-632.

${ }^{23}$ OLIVEIRA, Eugênio Pacelli de. Curso de processo penal. 13. ed. Rio de Janeiro: Lumen Juris, 2010, p. 149-152.

${ }^{24}$ Importante mencionar que a lei penal possibilita que a vítima desista da representação realizada; trata-se do instituto da retratação. A faculdade de retratação da representação, porém, possui um limite temporal, a saber: o oferecimento da denúncia pelo Ministério Público. Após oferecimento da denúncia pelo membro do parquet, por conseguinte, a vítima não mais poderá retratar.

${ }^{25}$ TÁVORA, Nestor; ALENCAR, Rosmar Rodrigues. Curso de direito processual penal. 3. ed. Salvador: Jus Podium, 2009, p. 128-129.

${ }^{26}$ JESCHECK, Hans-Heinrich; WEIGEND, Thomas. Tratado de derecho penal: parte general. 5. ed. Granada: Editorial Comares, 2002.
} 
-se também o fato de se tratar de um delito cujos sujeitos ativo e passivo são muito próximos e partilham de uma relação estreita; casos em que seria aconselhada uma intervenção distinta da penal $^{27}$. Por fim, e mais frequentemente, opta-se pelo condicionamento da ação penal ante o entendimento de que a vítima deve ser protegida contra novos danos (patrimoniais, morais, psicológicos ou sociais), que podem ser causados pelo proceder da ação penal ${ }^{28}$. Entende-se, portanto, que o processo penal pode provocar à vítima maiores prejuízos que os resultantes da prática do fato criminoso ${ }^{29}$. Nesse diapasão:

O Estado tem, desde o começo, interesse em que se proceda contra o crime; mas a esse interesse contrapõe-se terminantemente o do ofendido pelo não procedimento (pois a investigação e a discussão do fato, o streptus fori, não seriam para ele mais do que uma nova ofensa e talvez superior em gravidade à primeira). Por amor do ofendido, o Estado desiste do seu direito de fazer valer a pena ${ }^{30}$.

Por conseguinte, nessa modalidade de ação, a satisfação e a preservação da vontade da vítima ganham relevo. Existe, nesse contexto, um complexo embate entre os interesses do indivíduo e do Estado, em que há a prevalência do direito individual do ofendido em manter o crime ignorado em detrimento do direito estatal de punir, por se entender que o interesse da vítima goza de maior relevância ${ }^{31}$. Nesses casos, pois, o interesse da vítima se sobrepõe ao interesse público.

Tecidas essas considerações, voltemos à discussão sobre a ação penal no bojo da Lei n. 11.340/2006. Como foi a Lei n. 9.099/1995 que transformou a lesão corporal leve e a lesão corporal culposa em pública condicionada à representação ${ }^{32}$, para alguns doutrinadores, a interpretação da Lei Maria da Penha foi simples e sistemática: antes de 1995, conforme o Código Penal, os crimes de lesões corporais leves e culposas eram de ação penal pública incondicionada, mas, com o advento da Lei dos JECs, a ação penal destes crimes passou a ser pública condicionada à representação. A Lei n. 11.340/2006, por sua vez, vedou a aplicação da Lei dos Juizados Especiais Criminais aos crimes perpetrados contra a mulher no âmbito familiar e doméstico. Por conseguinte, desde que praticados neste contexto, a ação penal do crime de lesões corporais leves volta a ser pública incondicionada ${ }^{33}$.

Os que defendem ser a ação pública incondicionada argumentam, ainda, que esta é a regra, salvo nos casos em que a lei declara ser privativa do ofendido ou exija a representação da vítima ou a requisição do Ministro da Justiça. Quando foi criado o "tipo" da violência doméstica não se mencionou a espécie da ação, de modo que deveria ser entendida como pública incondicionada; posicionamento reforçado pelo art. 41 da Lei n. 11.340/2006, que proíbe a aplicação da Lei n. 9.099/1995. No mais, ressalta-se que a finalidade da Lei Maria da Penha foi o agravamento da situação do agressor, bem como impedir que a mulher manifestasse sua vontade sob o efeito de emoções ou coações ${ }^{34,35}$.

Os que preferem a ação penal condicionada, por sua vez, afirmam que a possibilidade de retratar concede à vítima um poderoso instrumento simbólico de negociação e assegura o equilíbrio entre as partes, pois a procedibilidade da ação penal está em suas mãos e, consequentemente, a possibilidade de condenação e prisão do agressor. Seria possibilitado, assim, o exercício de poder pela mulher dentro da relação, bem como se oportunizaria uma "conciliação civil", a qual, além de mais eficaz para a solução dos problemas vivenciados nas relações domésticas

\footnotetext{
${ }^{27}$ Note-se que as duas primeiras razões estão intimamente relacionadas às exigências de fragmentariedade e subsidiariedade do Direito penal.

${ }^{28}$ OLIVEIRA, Eugênio Pacelli de. Curso de processo penal, p. 149-150.

${ }^{29}$ SMANIO, Gianpaolo Poggio. Criminologia e Juizado Especial Criminal. São Paulo: Atlas, 1997, p. 41-42.

${ }^{30}$ ROMEIRO, Jorge Alberto. Da ação penal. 2. ed. Rio de Janeiro: Forense, 1978, p. 174.

${ }^{31}$ BITENCOURT, Cezar Roberto. Tratado de direito penal: parte geral. 10. ed. São Paulo: Saraiva, 2006, p. 851.

32 "Art. 88. Além das hipóteses do Código Penal e da legislação especial, dependerá de representação a ação penal relativa aos crimes de lesões corporais leves e lesões culposas."

${ }^{33}$ CAVALCANTI, Stela Valéria Soares de Farias. Violência doméstica contra a mulher no Brasil (análise da Lei "Maria da Penha", nº 11.340/06). Salvador: Jus Podivm, 2007, p. 157-158.

${ }^{34}$ CUNHA, Rogério Sanches; PINTO, Ronaldo Batista. Violência doméstica: Lei Maria da Penha (Lei 11.340/2006), comentada artigo por artigo. 2. ed. São Paulo: Revista dos Tribunais, 2008, p. 204-205.
} 
h- seja para a separação, seja para a reconciliação - melhor atende ao interesse da vítima, muitas vezes não voltado para a punição do agressor, mas para o rompimento do ciclo de violência e restabelecimento da paz no lar ${ }^{36}$.

No que tange à inovação trazida pelo artigo $16^{37}$ da Lei Maria da Penha, relativa à formalidade diferenciada na qual o ato da retratação deve estar envolto, a saber: necessidade de oitiva do Ministério Público e de a retratação da ofendi$\mathrm{da}^{38}$ ocorrer perante o Juiz em audiência especialmente designada para tal fim, afirma-se que tal novidade seria desnecessária se a preferência fosse dada à ação penal pública incondicionada. A audiência do art. 16 foi criada exatamente para conceder à mulher vítima a mais ampla garantia de independência quando da manifestação de sua vontade. No mais, a possibilidade de fazê-la até antes do recebimento da denúncia, a qual dilatou o prazo para retratação concedido pelo Código de Processo Penal, demonstra uma atenção redobrada aos frequentes casos em que as mulheres, solvidas as controvérsias domésticas e reestabelecidos os laços amorosos, optam por livrar o agressor do procedimento penal.

Entende-se, ainda, que a intenção do legislador ao afastar a Lei n. 9.099/1995 foi a de desligar o ideal de "baixa lesividade" das violências contra as mulheres e de evitar a aplicação dos institutos despenalizadores, responsáveis pela desconsideração da fala feminina e redução dos conflitos domésticos a questões pecuniárias; circunstâncias que provocaram a atribuição de culpa aos JECs pelo beneficiamento dos algozes femininos e "banalização" da violência doméstica. Ora, se existe um intento de consideração da fala feminina, conforme visto anteriormente, no âmbito do processo penal não há instituto que mais valorize a vontade das vítimas e considere as implicações do processo penal em suas vidas que a representação do ofendido e a sua retratabilidade. Não se trata, portanto, de beneficiar os supostos agressores, mas eleger como prioridade os anseios femininos.

No que tange ao medo de se atribuir um significado desagravante às lesões corporais leves praticadas contra as mulheres através da escolha da regra da ação penal pública condicionada, destaque-se o exemplo dos crimes contra a dignidade sexual, mais precisamente o estupro. É, o estupro, uma conduta menos gravosa por que se optou pela ação penal pública condicionada à representação? Não é o referencial da pena em abstrato do crime de estupro maior que o da violência doméstica? Por que, então, o legislador não escolheu outra ação penal para o referido crime sexual? Argumenta-se que a escolha da ação penal para os crimes sexuais foi exatamente evitar que o procedimento penal provocasse à vítima maiores prejuízos que os resultantes da prática do fato criminoso. Por que, então, com a violência doméstica, o critério deve ser diferente?

Ademais, qual o significado da categoria abstrata "gravidade"? Será que essa taxação é sufi-

\footnotetext{
${ }^{35}$ No dia 12/08/2008, a sexta turma do STJ se pronunciou sobre o tema entendendo ser a ação pública incondicionada ante os seguintes argumentos, dentre outros: "1) o art. 88 da Lei n. 9.099/1995 foi derrogado em relação à Lei Maria da Penha, em razão de o art. 41 deste diploma legal ter expressamente afastado a aplicação, por inteiro, daquela lei ao tipo descrito no art. $129, \S 9^{\circ}, \mathrm{CP} ; 2$ ) isso se deve ao fato de que as referidas leis possuem escopos diametralmente opostos. Enquanto a Lei dos Juizados Especiais busca evitar o início do processo penal, que poderá culminar em imposição de sanção ao agente, a Lei Maria da Penha procura punir com maior rigor o agressor que age às escondidas nos lares, pondo em risco a saúde de sua família; 3 ) a Lei n. 11.340/2006 procurou criar mecanismos para coibir a violência doméstica e familiar contra as mulheres nos termos do $\$ 8^{\circ}$ do art. 226 e art. 227, ambos da CF/1988, daí não se poder falar em representação quando a lesão corporal culposa ou dolosa simples atingir a mulher, em casos de violência doméstica, familiar ou íntima; 4) ademais, até a nova redação do $\$ 9^{\circ}$ do art. 129 do CP, dada pelo art. 44 da Lei n. $11.340 / 2006$, impondo pena máxima de três anos à lesão corporal leve qualificada praticada no âmbito familiar, corrobora a proibição da utilização do procedimento dos Juizados Especiais, afastando assim a exigência de representação da vítima. Ressalte-se que a divergência entendeu que a mesma Lei n. 11.340/2006, nos termos do art. 16, admite representação, bem como sua renúncia perante o juiz, em audiência especialmente designada para esse fim, antes do recebimento da denúncia, ouvido o Ministério Público.". Cf. BRASIL. Superior Tribunal de Justiça. Informativo de Jurisprudência n. 363, HC 96.992-DF, julgado em 12 ago. 2008. Disponível em: <http://jurisprudenciabrasil.blogspot.com.br/2008/12/informativo-sti-363-superior-tribunal.html>. Acesso em: 19 fev. 2014

${ }^{36}$ DIAS, Maria Berenice. A Lei Maria da Penha na justiça: a efetividade da Lei 11.340/2006 de combate à violência doméstica e familiar contra a mulher. 2. ed. São Paulo: Revista dos Tribunais, 2010, p. 158-159.

37 “Art. 16. Nas ações penais públicas condicionadas à representação da ofendida de que trata esta Lei, só será admitida a renúncia à representação perante o juiz, em audiência especialmente designada com tal finalidade, antes do recebimento da denúncia e ouvido o Ministério Público."

${ }^{38}$ Importante ressaltar que a redação do artigo 16 apresenta um problema: o legislador utilizou o termo "renúncia", quando, em verdade, deveria ser "retratação". A renúncia é uma causa de extinção da punibilidade que ocorre apenas na ação penal privada antes do oferecimento da queixa crime e nos crimes de ação pública condicionada anteriormente ao oferecimento da denúncia. Nesse caso, o direito de representação já foi exercido, tanto que o artigo reza: "antes do recebimento da denúncia". Por isso, para uma grande parte da doutrina, o legislador utilizou impropriamente o termo "renúncia" e quis referir-se à retratação da representação.
} 
ciente para determinar qual a melhor reação a uma situação problemática e efetivamente resolvê-la? O que possuem em comum e qual a garantia de que elementos como o "prejuízo gerado por um ato" e a "culpabilidade do autor" podem oferecer aos Juízes para que suas decisões afetem positivamente as pessoas diretamente interessadas no conflito? Não haveria outras formas diligentes de solução de situações difíceis ou de problemas sociais? A gravidade de um ato não deveria ser critério orientador da utilização do Direito Penal e, por conseguinte, a fuga à noção de gravidade de determinados atos pode acionar a utilização de meios mais eficazes de reação social $^{39}$.

Outrossim, na interpretação de uma lei, mister se faz analisar seus fins sociais, que, no caso da Lei n. 11.340/2006, certamente estão mais voltados para a proteção da vítima que para a severa punição do agressor. O artigo $4^{\circ}$ desta lei, inspirado na Lei de Introdução às Normas do Direito Brasileiro, quando dispõe sobre a necessidade de o Juiz aplicar a lei atendendo aos seus fins sociais, preceitua que, em sua interpretação, deverão ser considerados os fins sociais aos quais ela está destinada e, sobretudo, as condições particulares das mulheres atingidas pela violência doméstica e familiar.

A ordem voltada para a interpretação da lei conforme a sua finalidade social converge, pois, para a consideração das realidades sociais, dos impactos de uma norma sobre a sociedade e, principalmente, sobre os principais atingidos por ela. Deve haver uma harmonia entre a realidade e o jurídico, e o ser humano deve sempre ser o fim de uma lei; do contrário, ter-se-ia o in- fortúnio de o ser humano trabalhar em função da lei. Essa finalidade social da Lei Maria da Penha é facilmente identificada ao longo da leitura de seu conteúdo, o qual valoriza a mulher e sua incontestável e ativa intervenção no processo. A legislação opta por informar a vítima de todos os atos processuais (art. 21); prevê uma assistência integral, especializada e humanizada para a mulher (arts. 27 e 28); dispõe sobre a necessidade de um atendimento especializado e capacitado nas delegacias (arts. 11 e 12); e estabelece o trabalho da equipe multidisciplinar voltada para a vítima e sua família - arts. 29, 30 e $31^{40}$.

Por tudo exposto, tanto a $5^{\mathrm{a}}$ quanto a $6^{\mathrm{a}}$ Turmas do STJ ${ }^{41}$ decidiam em favor da ação penal pública condicionada à representação para o crime de lesões corporais leves no contexto da violência doméstica contra a mulher. Inclusive, no Juizado de Violência Doméstica e Familiar contra a Mulher da cidade do Recife, onde inicialmente era adotada a regra da ação penal pública incondicionada, optou-se, desde o ano de 2009, pela regra da ação penal pública condicionada à representação, dado que grande parte das vítimas desejava retratar e não prosseguir com a persecução penal do agressor depois de solvidas as controvérsias que mantinham o conflito. No entanto, recentemente, o STF, órgão capaz de oferecer resistência às estratégias expansionistas do Direito Penal, cedeu às pressões populares e dos movimentos feministas demandantes por maior rigor penal e, ao julgar a ADI n. $4424^{42}$, optou por limitar as possibilidades de diálogo e escolheu a regra da ação pública incondicionada à representação da ofendida, no caso da violência doméstica.

\footnotetext{
${ }^{39}$ CELIS, Jacqueline Bernat de; HULSMAN, Louk. Penas perdidas: o sistema penal em questão, p. 101-102.

${ }^{40}$ HERMANN, Leda Maria. Lei Maria da Penha: lei com nome de mulher - violência doméstica e familiar, considerações à Lei n. 11340/2006, comentada artigo por artigo. Campinas: Servanda, 2007, p. 251-252.

41 "Habeas Corpus. Processo penal. Crime de lesão corporal leve. Lei Maria da Penha. Natureza da ação penal. Representação da vítima. Necessidade. Ordem concedida. A Lei Maria da Penha é compatível com o instituto da representação, peculiar às ações penais públicas condicionadas e, dessa forma, a não-aplicação da Lei 9.099, prevista no art. 41 daquela lei, refere-se aos institutos despenalizadores nesta previstos, como a composição civil, a transação penal e a suspensão condicional do processo. [...] A garantia de livre e espontânea manifestação conferida à mulher pelo art. 16, na hipótese de renúncia à representação, que deve ocorrer perante o magistrado em audiência especialmente designada para este fim, justifica uma interpretação restritiva do artigo 41. O processamento do ofensor, mesmo contra a vontade da vítima, não é a melhor solução para as famílias que convivem com o problema da violência doméstica, pois a conscientização, a proteção das vítimas e o acompanhamento multidisciplinar com a participação de todos os envolvidos são medidas juridicamente adequadas, de preservação dos princípios do direito penal e que conferem eficácia ao comando constitucional de proteção à família. [...]". Ordem concedida para restabelecer a decisão proferida pelo juízo de 1. ${ }^{\circ}$ grau." Cf. BRASIL. Superior Tribunal de Justiça. Habeas Corpus $n$. 157416 MT 2009/0245373-4, T5 - Quinta Turma. Relator: Ministro Arnaldo Esteves Lima, julgado em 10 maio 2010. Disponível em: <http://stj.jusbrasil. com.br/jurisprudencia/9197982/habeas-corpus-hc-157416-mt-2009-0245373-4>. Acesso em: 20 fev. 2014.

${ }^{42}$ O STF, no dia 09/02/2012, julgou em plenário a Ação Direta de Constitucionalidade, proposta pela Procuradoria Geral da República, e decidiu pela constitucionalidade da Lei n. 11.340/2006 e pela ação penal pública incondicionada do crime de violência doméstica.
} 
No julgamento ${ }^{43}$ da mencionada ADI, nas argumentações favoráveis à ação penal pública incondicionada, em que pese a afirmação de que o julgamento se deu com base na realidade da violência de gênero, pôde-se encontrar referências à "fragilidade feminina", à "prevenção contra coações no decorrer da ação penal" e à "irracionalidade da mulher no que tange à escolha pela não intervenção punitiva Estatal" como fatores orientadores da escolha da ação penal pública incondicionada. A fuga ao senso comum da violência contra a mulher foi observada apenas no vencido voto do Ministro Cezar Peluso, que afirmou ser consequência do respeito aos direitos humanos a atenção à vontade das mulheres, sujeitos capazes de autodeterminação e, portanto, da possibilidade de escolha sobre o seu destino.

Inobstante ter sido voto vencido, evidentemente, o seu conteúdo é muito mais adequado à realidade da violência doméstica, bem como à tentativa de erradicação da desigualdade de gênero e desconstrução de uma suposta fragilidade feminina. Nesse contexto, preocupam abordagens como as dos Ministros vencedores que, sob o pretexto de representarem uma conquista para as mulheres, podem impor práticas que afastam o fenômeno da violência doméstica do real e do vivido, ocultam sua coerente compreensão e acabam por perenizar falsas práticas protetoras porque fomentam os processos de opressão que deveriam rechaçar ${ }^{44}$.

Ora, a vítima apresenta dificuldades na denúncia do companheiro, por quem ainda possui sentimentos, pai de seus filhos e muitas vezes financiador do lar. Logo, a rigidez da legislação, que impossibilita a retratação e torna irreversível o procedimento processual penal, inibiria a procura pela ajuda judiciária, contribuindo para o silêncio, o temor das vítimas e o incremento das "cifras ocultas" da violência doméstica e familiar contra a mulher ${ }^{45}$. Desta feita, o próprio instrumento reservado à proteção feminina irá, de todas as formas, penalizá-la.

Nesse contexto, o sistema penal não consegue solucionar os problemas que se propõe erradicar e as mulheres, vítimas da violência doméstica e familiar, em grande parte, não desejam a persecução penal de seus agressores; resta, unicamente, a irracionalidade da utilização de medidas punitivas para a solução dos conflitos domésticos.

Certamente o caminho para a solução do conflito não passa pela criminalização, muito menos pela carcerização do agressor, na medida em que o sistema penal, em especial a pena de prisão, não oferece mais que uma falácia ideológica em termos de ressocialização do agente, além de operar seletivamente distribuindo desigualmente a retribuição que apregoa [...]. Esse mesmo sistema, ademais, não faz pelas vítimas mais que duplicar as suas dores, expondo-as a um ritual indiferente e formal, que desconsidera a diversidade inerente à condição humana e reproduz os valores patriarcais que a conduziram até ele. Aportando ao sistema penal, a vítima, mais do que nunca, distancia-se de seu desiderato de reformular a convivência doméstica, porque deflagra um aparato que não esta munido dos mecanismos necessários para a mediação do conflito, o que a leva a retirar-se do espaço público que conquistou ao longo de uma história de lutas, para retornar à esfera do privado, desmuniciada de qualquer resposta ${ }^{46}$.

Reconhecer a violência doméstica e familiar contra a mulher como um problema social, portanto, não implica que o Direito Penal seja a melhor solução. Clara é a orientação para um Direito Penal de ultima ratio no ordenamento jurídico, tal que a Constituição estabelece inúme-

\footnotetext{
${ }^{43}$ De caráter vinculante, o julgamento do STF "forçou" a modificação do entendimento consolidado no STJ, conforme se observa em seu informativo n. 509: "DIREITO PENAL E PROCESSUAL PENAL. LESÃO CORPORAL LEVE OU CULPOSA NO ÂMBITO DOMÉSTICO. AÇÃO PENAL PÚBLICA INCONDICIONADA. O crime de lesão corporal, mesmo que leve ou culposa, praticado contra a mulher, no âmbito das relações domésticas, deve ser processado mediante ação penal pública incondicionada. No julgamento da ADI 4.424-DF, o STF declarou a constitucionalidade do art. 41 da Lei $\mathrm{n}$. 11.340/2006, afastando a incidência da Lei n. 9.099/1995 aos crimes praticados com violência doméstica e familiar contra a mulher, independentemente da pena prevista. Precedente citado do STF: ADI 4.424-DF, DJe 17/2/2012; do STJ: AgRg no REsp 1.166.736-ES, DJe 8/10/2012, e HC 242.458-DF, DJe 19/9/2012. AREsp 40.934-DF, Rel. Min. Marilza Maynard (Desembargadora convocada do TJ-SE), julgado em 13/11/2012.”. BRASIL. Superior Tribunal de Justiça. Informativo de Jurisprudência n. 509, julgado em 13 nov. 2012. Disponível em: <www.stj.jus.br/docs_internet/informativos/RTF/Inf0509. rtf $>$. Acesso em: 19 fev. 2014.

${ }^{44}$ GROSSI, Patrícia Krieger; AGUINSKY, Beatriz Gershenson. Por uma nova ótica e uma nova ética na abordagem da violência contra mulheres nas relações conjugais. In: GROSSI, Patrícia Krieger (Coord.). Violências e gênero: coisas que a gente não gostaria de saber. 2. ed. Porto Alegre: ediPUCRS, 2012, p. 25.

${ }^{45}$ CELMER, Elisa Girotti; AZEVEDO, Rodrigo Ghiringhelli de. Violência de gênero, produção legislativa e discurso punitivo: uma análise da Lei 11.340/2006. Boletim IBCCRIM, n. 170, p. 15-17, jan. 2007, p. 15-17.

${ }^{46}$ HERMANN, Leda Maria. Violência doméstica e os juizados especiais criminais: a dor que a lei esqueceu, p. 18-19.
} 
ros princípios limitadores da intervenção Estatal por meio de seu poder de punir. Por conseguinte, à compreensão da intervenção penal como a forma mais gravosa e violenta de ingerência na liberdade do indivíduo, pôs-se o Direito Penal para a limitação máxima da criminalização, dos arbítrios decisórios, bem como da aflição da punição ${ }^{47}$.

Conquanto não esteja previsto expressamente no bojo da Constituição, o princípio da intervenção mínima constitui norte categórico ao legislativo e intérprete da lei. Ele está intimamente relacionado ao caráter fragmentário e subsidiário do Direito Penal, os quais significam, respectivamente, a autonomia do Direito Penal, bem como a reserva de sua utilização para os casos em que outras respostas protetoras fracassem em sua finalidade. Ignorar o princípio da intervenção mínima, portanto, implica socorrer-se prioritária e principalmente da tutela penal de bens jurí$\operatorname{dicos}^{48}$. No entanto, "se outras formas de sanção se revelam suficientes para a tutela desse bem, a criminalização é incorreta. Somente se a sanção penal for instrumento indispensável de proteção jurídica é que a mesma se legitima" ${ }^{39}$.

Em pesquisa realizada no Rio Grande do Sul, foi possível a constatação de que as mulheres, em detrimento das soluções penais, preferem a utilização das medidas protetivas, que, nesse contexto, perderam a sua natureza cautelar e passaram a ser medidas efetivamente satisfativas do conflito $^{50}$.

Importante, pois, que sejam discutidos meios alternativos para a solução de conflitos, principalmente por meio da transferência da responsabilidade para outros ramos do Direito, como também pela utilização de medidas psicoterapêuticas, conciliadoras e pedagógicas, rompendo assim com o paradigma penalista tradicional de que só se resolve o problema da criminalidade com a energia penal.

A minimização da intervenção do sistema pe- nal, ademais, não implica ignorar a prática dos crimes contra a mulher no contexto doméstico, mas, unicamente, na utilização do Direito Penal conforme os princípios que o rege, confluentes para máxima contração do paradoxal sistema punitivo. Muito mais adequada, portanto, a escolha pela ação penal pública condicionada à representação da vítima, quando se tratar do crime de violência doméstica, por se adequar aos anseios femininos e aos postulados de mínima intervenção.

\section{EM BUSCA DE UMA CONCLUSÃO: O LU- GAR DO DIREITO PENAL NO CONFLITO DOMÉSTICO}

A violência doméstica e familiar contra a mulher, durante muito tempo, foi legitimada como forma de controle sobre as mulheres na sociedade patriarcal brasileira. Com a paulatina conquista do espaço público e de direitos igualitários pelas mulheres, a realidade da legitimação da violência foi modificada. A alarmante presença de inúmeros casos de violência doméstica e familiar contra a mulher, até então desconhecidos (ou ignorados) na sociedade brasileira, foi evidenciada nos Juizados Especiais Criminais. No entanto, para uma grande parcela da população, as soluções dadas à violência de gênero nestes Juizados eram ineficazes, por não compreenderem a natureza específica da violência doméstica, desconsiderando a histórica relação hierarquizada e de poder sobre as mulheres no ambiente familiar.

Destarte, com a intenção de criar mecanismos para coibir e prevenir esse tipo de violência, o Legislativo criou a Lei n. 11.340/2006, popularmente conhecida como Lei "Maria da Penha". A legislação surgiu no cenário jurídico nacional como resposta política às fortes demandas midiáticas e populacionais, principalmente dos movimentos sociais feministas, por ações mais

\footnotetext{
${ }^{47}$ FERRAJOLI, Luigi. A pena em uma sociedade democrática. Discursos sediciosos: crime, direito e sociedade. Rio Janeiro, n. 7, p. 31-40, 2. sem, 2002, p. 32-33.

${ }^{48}$ BATISTA, Nilo. Introdução crítica ao direito penal brasileiro. 12. ed. Rio de Janeiro: Revan, 2011, p. 84-86.

${ }^{49}$ LUISI, Luiz. Os princípios constitucionais penais. 2. ed. Porto Alegre: Sergio Antonio Fabris, 2003, p. 38-39.

${ }^{50}$ CELMER, Elisa Girotti et al. Sistema penal e relações de gênero: violência e conflitualidade nos juizados de violência doméstica e familiar contra a mulher na cidade do Rio Grande (RS/Brasil). In: AZEVEDO, Rodrigo Ghiringhelli de (Org.). Relações de gênero e sistema penal: violência e conflitualidade nos juizados de violência doméstica e familiar contra a mulher. Porto Alegre: EDIPUCRS, 2011, p. 101.
} 
incisivas contra a criminalidade doméstica. No contexto de oferta de respostas mais enérgicas contra a criminalidade doméstica e tentativa de erradicação dos "benefícios" concedidos aos agressores de mulheres, preferiu-se interpretar amplamente o artigo 41 da referida lei e, portanto, aplicar a regra da ação penal pública incondicionada ao crime de violência doméstica.

A aposta no Direito Penal para lidar com os crimes praticados contra as mulheres no contexto doméstico, no entanto, deu-se com base na falsa percepção do fenômeno da violência contra a mulher.

Ao longo deste trabalho, observou-se que a intervenção do sistema penal nos conflitos domésticos acaba por gerar consequências negativas sobre as próprias mulheres vítimas e suas famílias. Constata-se, pois, uma (re)vitimização feminina com a existência do procedimento penal. As mulheres em situação de violência normalmente não almejam a persecução penal de seus agressores, mas o rompimento do ciclo de violência e o restabelecimento da paz no lar.

Nesse contexto, quando tomam conhecimento da possibilidade de privação da liberdade do sujeito ativo, as vítimas têm dificuldades em denunciar o abuso sofrido. Com efeito, a irreversibilidade do procedimento processual penal findará por inibir a procura do auxílio judicial e contribuir para o renascer das "cifras ocultas" da violência doméstica contra a mulher, pois o próprio instrumento reservado à proteção feminina irá penalizá-la.

Frente aos interesses opostos da vítima, no que tange à intervenção penal no conflito, as razões de política criminal que pautam a opção legislativa pela ação penal pública condicionada - a saber: a proximidade dos sujeitos ativo e passivo que partilham de uma relação estreita e a proteção da vítima contra novos danos, que podem ser causados pelo próprio processo - devem ser evocadas em atenção às mulheres em situação de violência. É evidente a incapacidade da superação dos conflitos interpessoais pela via formal da justiça criminal, visto que ela se apropria do conflito das vítimas, fugindo aos propósitos de escuta das partes envolvidas, não apresentando soluções e efeitos positivos sobre os envolvidos, sequer previne as situações de violência.

Logo, paradoxalmente, a lei que surgiu com a finalidade de prevenir e erradicar a violência doméstica e familiar contra a mulher, por haver retirado a fala feminina do espaço público e não ter contemplado as peculiaridades dos conflitos de gênero e a falência do sistema punitivo, pode contribuir para a ocultação dos dados relativos à violência, já que as mulheres vítimas preferem o silêncio à dolorosa e ineficiente intervenção do sistema penal no ambiente doméstico. Nesse contexto, é urgente que se ampliem as discussões a respeito das melhores formas de resolução dos conflitos domésticos para além do sistema penal e, por ora, confira-se à vítima a possibilidade de avaliar, conforme valorações íntimas, a oportunidade e a conveniência da ação penal.

\section{REFERÊNCIAS}

ALENCAR, Daniele Nunes de; MELLO, Marília Montenegro Pessoa de. A Lei Maria da Penha e sua aplicação na cidade de Recife: uma análise crítica do perfil do "agressor" nos casos que chegam ao Juizado da mulher (anos 2007-2008). Revista Sociais e Humanas. v. 24, n. 2, p. 9-21, jul./ dez. 2011.

ANDRADE, Vera Regina Pereira de. Minimalismos e abolicionismos: a crise do sistema penal entre a deslegitimação e a expansão. Revista da ESMESC, Florianópolis, v. 13, n. 19, jan./dez. 2006.

BARATTA, Alessandro. O paradigma do gênero: da questão criminal à questão humana. In: CAMPOS, Carmen Hein de (Org.). Criminologia e feminismo. Porto Alegre: Sulina, 1999.

BATISTA, Nilo. Introdução crítica ao direito penal brasileiro. 12. ed. Rio de Janeiro: Revan, 2011.

BITENCOURT, Cezar Roberto. Tratado de direito penal: parte geral. 10. ed. São Paulo: Saraiva, 2006.

BRASIL. Decreto-lei n. 2.848, de 7 de dezembro 
de 1940. Código Penal. Mini Códigos: Penal. 15. ed. São Paulo, SP: Revista dos Tribunais, 2013.

BRASIL. Lei n. 9.099, de 26 de setembro de 1995. Dispõe sobre os Juizados Especiais Cíveis e Criminais e dá outras providências. Mini Códigos: Penal. 15. ed. São Paulo, SP: Revista dos Tribunais, 2013.

BRASIL. Lei n. 11.340, de 7 de agosto de 2006. Mini Códigos: Penal. 15. ed. São Paulo, SP: Revista dos Tribunais, 2013.

BRASIL. Superior Tribunal de Justiça. Habeas Corpus n. 157416 MT 2009/0245373-4, T5 - Quinta Turma. Relator: Ministro Arnaldo Esteves Lima, julgado em 10 maio 2010. Disponível em: <http://stj.jusbrasil.com.br/jurisprudencia/9197982/habeas-corpus-hc-157416-mt-2009-0245373-4>. Acesso em: 20 fev. 2014.

BRASIL. Superior Tribunal de Justiça. Informativo de Jurisprudência n. 363, HC 96.992-DF, julgado em 12 ago. 2008. Disponível em: <http:// jurisprudenciabrasil.blogspot.com.br/2008/12/ informativo-stj-363-superior-tribunal.html $>$. Acesso em: 19 fev. 2014.

BRASIL. Superior Tribunal de Justiça. Informativo de Jurisprudência n. 509, julgado em 13 nov. 2012. Disponível em: <www.stj.jus.br/docs_internet/informativos/RTF/Inf0509.rtf>. Acesso em: 19 fev. 2014.

CAMPOS, Carmen Hein de; CARVALHO, Salo de. Violência doméstica e Juizados Especiais Criminais: análise a partir do feminismo e do garantismo. Revista Estudos Feministas, Florianópolis, v. 14, n. 2, p. 409-422, maio/ago. 2006.

Tensões atuais entre a criminologia feminista e a criminologia crítica: a experiência brasileira. In: (Org.). Lei Maria da Penha comentada em uma perspectiva jurídico-feminista. Rio de Janeiro: Lumen Juris, 2011.

CAVALCANTI, Stela Valéria Soares de Farias. Violência doméstica contra a mulher no Brasil (análise da Lei "Maria da Penha", no 11.340/06). Salvador: Jus Podivm, 2007.

CUNHA, Rogério Sanches; PINTO, Ronaldo Batista. Violência doméstica: Lei Maria da Penha (Lei 11.340/2006), comentada artigo por artigo. 2. ed. São Paulo: Revista dos Tribunais, 2008.

CELIS, Jacqueline Bernat de; HULSMAN, Louk. Penas perdidas: o sistema penal em questão. Niterói: Luam, 1993.

CELMER, Elisa Girotti. Sistema penal e relações de gênero: uma análise de casos referentes à Lei 11.340/06 na comarca do Rio Grande/RS. In: SEMINÁRIO INTERNACIONAL FAZENDO GÊNERO, 9, 2010, Florianópolis. Anais... [recurso eletrônico] / Seminário Internacional Fazendo Gênero 9: diásporas, diversidades, deslocamentos. Florianópolis: Universidade Federal de Santa Catarina, 2010. p. 1-9. Disponível em: $<$ http://www.fazendogenero.ufsc.br/9/resources/anais/1278298189_ARQUIVO_SISTEMAPENALERELACOESDEGENERO-fazendogenero.pdf >. Acesso em: 13 mar. 2012.

; AZEVEDO, Rodrigo Ghiringhelli de. Violência de gênero, produção legislativa e discurso punitivo: uma análise da Lei 11.340/2006. Boletim IBCCRIM, n. 170, p. 15-17, jan. 2007.

et al. Sistema penal e relações de gênero: violência e conflitualidade nos juizados de violência doméstica e familiar contra a mulher na cidade do Rio Grande (RS/Brasil). In: AZEVEDO, Rodrigo Ghiringhelli de (Org.). Relações de gênero e sistema penal: violência e conflitualidade nos juizados de violência doméstica e familiar contra a mulher. Porto Alegre: EDIPUCRS, 2011.

DIAS, Maria Berenice. A Lei Maria da Penha na justiça: a efetividade da Lei 11.340/2006 de combate à violência doméstica e familiar contra a mulher. 2. ed. São Paulo: Revista dos Tribunais, 2010.

FAYET JÚNIOR, Ney; VARELA, Amanda Gual- 
tieri. A ação (penal) privada subsidiária da pública: das vantagens ou desvantagens da participação do ofendido na atividade jurídico-penal. Porto Alegre: Elegantia Juris, 2014.

FERRAJOLI, Luigi. A pena em uma sociedade democrática. Discursos sediciosos: crime, direito e sociedade. Rio Janeiro, n. 7, p. 31-40, 2. sem, 2002.

GARLAND, David. A cultura do controle: crime e ordem social na sociedade contemporânea. Rio de Janeiro: Revan, 2008.

GOMES, Carla de Castro; MORAES, Aparecida Fonseca. O caleidoscópio da violência conjugal: instituições, atores e políticas públicas no Rio de Janeiro. In: MORAES, Aparecida Fonseca; SORJ, Bila (Coord.). Gênero, violência e direitos na sociedade brasileira. Rio de Janeiro: 7 letras, 2009.

GRECO, Rogério. Código Penal: comentado. 4. ed. Niterói: Impetus, 2010.

GROSSI, Patrícia Krieger; AGUINSKY, Beatriz Gershenson. Por uma nova ótica e uma nova ética na abordagem da violência contra mulheres nas relações conjugais. In: GROSSI, Patrícia Krieger (Coord.). Violências e gênero: coisas que a gente não gostaria de saber. 2. ed. Porto Alegre: ediPUCRS, 2012.

HERMANN, Leda Maria. Violência doméstica e os juizados especiais criminais: a dor que a lei esqueceu. Campinas: Servanda, 2002.

Lei Maria da Penha: lei com nome de mulher - violência doméstica e familiar, considerações à Lei n. 11340/2006, comentada artigo por artigo. Campinas: Servanda, 2007.

JESCHECK, Hans-Heinrich; WEIGEND, Thomas. Tratado de derecho penal: parte general. 5 . ed. Granada: Editorial Comares, 2002.

LARRAURI, Elena. La intervencion penal para resolver un problema social. Revista Argentina de Teoría Jurídica, Buenos Aires, v. 11, n. 1, p.
01-22, ago. 2011.

LEMGRUBER, Julita. A mulher e o sistema de justiça criminal - Algumas notas. Revista Brasileira de Ciências Criminais, n. 36, p. 381, out.-dez. 2001.

LUISI, Luiz. Os princípios constitucionais penais. 2. ed. Porto Alegre: Sergio Antonio Fabris, 2003.

MELLO, Marília Montenegro Pessoa de. Lei de violência doméstica: Lei no 11.340/2006. In: DAOUN, Alexandre Jean; FLORÊNCIO FILHO, Marco Aurélio (Coord.). Leis penais comentadas. São Paulo: Quartier Latin, 2009, p. 466.

MORAES, Aparecida Fonseca; SORJ, Bila. Os paradoxos da expansão dos direitos das mulheres no Brasil. In: MORAES, Aparecida Fonseca; SORJ, Bila (Coord.). Gênero, violência e direitos na sociedade brasileira. Rio de Janeiro: 7 letras, 2009.

OLIVEIRA, Eugênio Pacelli de. Curso de processo penal. 13. ed. Rio de Janeiro: Lumen Juris, 2010.

OTERO, Juan Manuel. A hipocrisia e a dor no sistema de sanções do direito penal. Discursos Sediciosos: crime, direito e sociedade, Rio de Janeiro, ano 12 , n. 15/16, p. 45-63, 2007, 1 e 2 semestres 2008 .

PASINATO, Wânia. Violência contra as mulheres e legislação especial, ter ou não ter? Eis uma questão. Revista Brasileira de Ciências Criminais. São Paulo, Revista dos Tribunais, n. 70, p. 321360, jan.-fev. 2008.

REINER, Robert. Media-made criminality: the representation of crime in the mass media. In: MAGUIRE, Mike; MORGAN, Rod; REINER, Robert (Comp.). The Oxford handbook of criminology. 4. ed. New York: Oxford University Press, 2007.

ROMEIRO, Jorge Alberto. Da ação penal. 2. ed. Rio de Janeiro: Forense, 1978.

ROMEIRO, Julieta. A Lei Maria da Penha e os 
desafios da institucionalização da "violência conjugal" no Brasil. In: MORAES, Aparecida Fonseca; SORJ, Bila (Coord.). Gênero, violência e direitos na sociedade brasileira. Rio de Janeiro: 7 letras, 2009.

SANTOS, Juarez Cirino dos. Direito penal: parte geral. 4. ed. Florianópolis: Conceito Editorial, 2010.

SMANIO, Gianpaolo Poggio. Criminologia e Juizado Especial Criminal. São Paulo: Atlas, 1997.

SUTHERLAND, Edwin Hardin. White collar crime: the uncut version. New Haven: Yale University Press, 1985.

TÁVORA, Nestor; ALENCAR, Rosmar Rodrigues. Curso de direito processual penal. 3. ed. Sal-vador: Jus Podium, 2009. 